\title{
Barriers to High Court appointments in Northern Ireland
}

\author{
JOHN MORISON, \\ BRICE DICKSON
}

\author{
AND \\ ANDREW GODDEN* \\ Queen's University Belfast
}

\begin{abstract}
This article reports on research carried out on why the Northern Ireland Judicial Appointments Commission is finding it difficult to attract applicants of the appropriate quality for vacant High Court appointments. It makes recommendations for how the appointments system might be changed.
\end{abstract}

Keywords: High Court appointments; barriers to judicial appointments

\section{Introduction}

$\mathrm{T}$ his article examines a significant problem in the legal system of Northern Ireland - the difficulty in recruiting lawyers with the requisite skills to serve as High Court judges. It summarises and slightly expands upon research which two of us were commissioned to conduct for the Northern Ireland Judicial Appointments Commission (NIJAC) in early 2019. ${ }^{1}$ The research questions were: what are the real and perceived barriers that may be influencing those at relatively senior levels in the legal professions (widely defined) when they are making decisions about whether to apply for a High Court position and how might those barriers be overcome?

It had become apparent that such positions were not as attractive to potential applicants as in previous years. In its submission to the Review Body on Senior Salaries in 2018, the High Court Judges' Association of Northern Ireland expressed the view that the unsuccessful recruitment round for High Court appointments conducted in 2016 was evidence that the role was not sufficiently rewarding to make legal practitioners want to give up their much higher incomes derived from private practice. The Association

* Respectively, Professor of Jurisprudence, Emeritus Professor of International and Comparative Law and Lecturer in Law, all at the School of Law, Queen's University Belfast. We are very grateful to the two anonymous reviewers who commented on an earlier draft of this article. The views herein expressed, and the responsibility for any errors, remain ours alone.

1 Barriers to High Court Appointments in Northern Ireland, submitted to NIJAC in June 2019. The research was assisted by Leah Trainor, a doctoral student in the School of Law at Queen's University Belfast. NIJAC has not yet placed the report on its website < www.nijac.gov.uk>. In its Business Plan for 2019/2020 one of NIJAC's objectives is to 'develop, implement and deliver a programme of action to attract applications [for the judiciary] from the widest possible pool', and its first key milestone in delivering that objective is listed as 'Analysis and dissemination of QUB research findings by March 2020': see <www.nijac.gov.uk/sites/nijac/files/media-files/NIJAC\%20Business\%20Plan\%2020192020\%20Reviewed $\% 20$ November\%202019_0.pdf $>$. 
described the failure to fill three posts out of the statutory complement of 10 as 'little short of disastrous'. ${ }^{2}$ Happily, two of the three vacancies were filled in 2018, but one vacancy remained. A competition for that post took place during 2019 but, again, NIJAC felt unable to make an appointment from those who applied for it.

The research into the barriers to High Court appointments in Northern Ireland took full account of existing literature in the field, especially in relation to High Court appointments in England and Wales, where there have been even more serious recruitment difficulties than in Northern Ireland. ${ }^{3}$ NIJAC permitted the research to be conducted without any interference or influence, and the views expressed by our interviewees and consultees were cross-checked to ensure that we were being as objective as possible in stating and assessing them. Our findings largely mirror those reached by researchers in England and Wales: dissatisfaction with the pay and pension associated with a High Court position plays a large role in putting off applicants who are already earning more at the Bar or as senior solicitors; the nature of the High Court's role is less appealing than it was because the workload involved is more onerous than ever and the ability to work flexibly is less than in the private sector, or even in public-sector legal bodies such as the Public Prosecution Service; the judicial role continues to be a lonely one, with little assistance provided for research, whereas senior lawyers often greatly enjoy operating in partnership with other lawyers; and the presumption continues to prevail that the applicants best suited to the High Court bench are Queen's Counsel who have spent years impressing judges already on the bench with their advocacy skills, while other attributes required for success as a judge are, relatively speaking, downplayed, a situation which might reflect unconscious bias.

Interviews and consultations were conducted with a large number of interested parties: barristers, solicitors, lawyers working in the public sector, currently serving County Court and High Court judges, and retired County Court and High Court judges. A total of 50 lawyers - 31 male and 19 female - engaged with our fieldwork, 25 through one-to-one interviews and 25 through participation in group discussions. They comprised 18 serving or retired judges (including seven serving High Court judges), 12 solicitors, eight barristers (all QCs), six salaried judges working in tribunals, and six lawyers employed in government legal services. We guaranteed anonymity to all of the interviewees and consultees, but each of them granted us permission to use our discretion in quoting what they said. Gender dimensions, while clearly present and significant, were not a particular focus of this research as they were addressed in earlier work, ${ }^{4}$ but many of the structural issues about progression within the legal profession play out at the point where appointment to the High Court is being considered.

In our interviews we tended to focus on the headline issues raised in the Turenne and Bell report from 2018, because many of the challenges facing potential applicants for High Court positions in Northern Ireland are likely to be the same as those arising in England and Wales. Northern Ireland is different, however, in that its smallness as a jurisdiction means that lawyers there are not as able as those in England and Wales to specialise in particular areas of law, to serve as part-time judges while maintaining their

2 Copy of submission on file with the authors.

3 Much of the relevant literature is alluded to in Sophie Turenne and John Bell, The Attractiveness of Judicial Appointments in the United Kingdom: Report to the Senior Salaries Review Body (2018), available at <https://assets.publishing.service.gov.uk/government/uploads/system/uploads/attachment_data/file/7485 80/SSRB_Report_Attractiveness_Turenne-Bell_Revised_14_March_FINAL_-_temp_pdf.pdf >.

4 See e.g. Rewarding Merit in Judicial Appointments? A Research Project Undertaken by the School of Law, Queen's University Belfast for the Northern Ireland Judicial Appointments Commission (2013). 
practices without risking a conflict of interest, or to keep confidential the fact that they are applying for a judicial post.

Our five group discussions functioned similarly, with the questions asked of the group being close to those asked of individual interviewees. Only one of the five groups contained serving judges (some salaried, some fee-paid). This was the 'Group of Presiders', that is, judges who have been asked by the Lord Chief Justice to preside over the group of courts or tribunals within which they are a judge, such as the County Courts, the magistrates' courts, the industrial tribunals (called employment tribunals in England and Wales), appeal tribunals (for welfare benefit claims) and the criminal injuries compensation appeals panel. The other four groups comprised solicitors (two groups), lawyers working for the Public Prosecution Service, and staff from the Crown Solicitor's Office. The opinions expressed during the group discussions were added to those expressed by individual interviewees and all were then assessed as a whole.

\section{The High COURT OF Northern Ireland}

As in England and Wales, the High Court of Northern Ireland constitutes the highest level court for first instance hearings in the jurisdiction. Its powers are set out in sections 16 to $33 \mathrm{~A}$ of the Judicature (NI) Act 1978, as amended. Since 2004 the currently permitted number of High Court judges is 10, not including the Lord Chief Justice or the three Lords Justices of Appeal. ${ }^{5}$ At present only eight of the 10 High Court positions are filled. ${ }^{6}$ There are currently two women judges in the High Court and a further recently appointed judge was previously a solicitor. The vast bulk of High Court work is in the area of civil law, although High Court judges do occasionally sit in the Crown Court to hear serious criminal cases, and in the High Court they hear judicial review applications relating to criminal causes or matters. Unlike their High Court colleagues in England and Wales, however, they do not hear appeals from criminal cases in magistrates' courts, a task which is assigned instead to County Court judges, who also handle many other serious criminal cases. ${ }^{7}$ Occasionally, High Court judges will also sit in the Court of Appeal of Northern Ireland. Between them they are called upon to perform more than 60 other tasks at the Lord Chief Justice's request, ranging from being a Judge-in-Residence at Ulster University or Queen's University Belfast (positions which carry relatively light duties) to chairing bodies such as the Council of Legal Education or the Boundary Commission for Northern Ireland (which at certain times can be onerous responsibilities). There is a particular problem with so-called 'legacy' inquests relating to deaths which occurred during the conflict in Northern Ireland between 1969 and 1998. To help solve this problem the Lord Chief Justice has been appointed President of the Coroners' Court, Mrs Justice Keegan has been appointed head of the Coroners Service 8

5 S 2(1) of the Judicature (NI) Act 1978, as amended by Art 2 of the Maximum Number of Judges (NI) Order 2004 (SI 1985), provides: 'The High Court shall consist of the Lord Chief Justice of Northern Ireland (in this Act referred to as "the Lord Chief Justice") and not more than ten puisne judges who shall be styled "Judges of the High Court".

6 In addition to the vacancy which was competed for but not filled in 2019, a further vacancy was created when Sir Bernard McCloskey was promoted from the High Court to the Court of Appeal in September 2019.

7 For more on the role of County Court judges see pp 494-496 below.

8 For more details, see <www.justice-ni.gov.uk/articles/coroners-service-northern-ireland>. 
and individual High Court judges have at times been asked to conduct particularly controversial inquests. ${ }^{\text {? }}$

Applicants for vacancies on the High Court are recommended for appointment by NIJAC after responding to an advertisement and undergoing a rigorous selection process. NIJAC was established in 2005 under the Justice (NI) Act 2002, amended by the Justice (NI) Act 2004. In the years between 2008 and 2018 it organised seven competitions for High Court appointments. ${ }^{10}$ In total there were 55 applicants for the posts, of whom 20 were shortlisted, and 10 were eventually offered a post. Of these 10, nine were Queen's Counsel and one was a senior solicitor. No County Court judge has been appointed to the High Court since NIJAC was established, even though there have been a number of applications from County Court judges. In this context it is worth bearing in mind the words of the Lord Chief Justice of England and Wales, Lord Burnett, in his Treasurer's Lecture delivered on 18 February 2019: 'if the judiciary is not appointed from every corner of the legal professions, talented people will be missed and the overall quality of the judiciary will suffer'. ${ }^{11}$

\section{THE FINDINGS OF RESEARCH ALREADY CONDUCTED}

The supposed 'recruitment crisis' presently facing the judiciary in general has attracted some recent attention. ${ }^{12}$ We already know quite a lot about its nature and possible causes. In the UK work on the theme began in $1998,{ }^{13}$ and the most recent study was completed in 2018 by Turenne and Bell. ${ }^{14}$ This builds upon findings in annual Judicial Attitudes Surveys from 2014 and 2016, ${ }^{15}$ continuing interest from the Review Body on Senior Salaries ${ }^{16}$ and work done by the House of Lords Select Committee on the Constitution. ${ }^{17}$

9 E.g. into the 'Ballymurphy massacre', when 10 civilians were allegedly killed by British soldiers in the 72-hour period following the introduction of internment on 9 August 1971: see <https://judiciaryni.uk/ballymurphyinquest>. Keegan J is due to give her verdict in that inquest during the first half of 2020. In November 2019 she announced a provisional timetable for the completion of the remaining 38 legacy inquests, some of which involve multiple deaths: see <https://judiciaryni.uk/sites/judiciary/files/media-files/ Presiding $\% 20$ Coroner $\% 27 \mathrm{~s} \% 20$ Statement $\% 20$ in $\% 20$ relation $\% 20$ to $\% 20$ legacy $\% 20$ inquests $\% 20$ $\% 2020 \% 20$ Nov $\% 202019$.pdf $>$.

10 By the end of 2019 NIJAC had not disclosed how many applicants there were for the 2019 competition.

11 'A Changing Judiciary in a Modern Age', 5, available at <www.judiciary.uk/wp-content/uploads/2019/02/mttreasurers-lecture-final-for-publishing.pdf $>$.

12 See, for example, Adrian Jack, 'A Low Benchmark?' New Law Journal (London, 12 January 2017) 6; 'The Recruitment Crisis is Damaging Every Level of the Judiciary' The Times (London, 8 March 2018); Michael Beloff, 'Judge Not: Few QCs these Days Aspire to the Bench', The Spectator (London, 25 June 2019). See also Judiciary of England and Wales, The Lord Chief Justice's Report (2017).

13 Hazel Genn, The Attractiveness of Senior Judicial Appointment to Highly Qualified Practitioners (Judicial Executive Board 2008) <www.ucl.ac.uk/judicial-institute/sites/judicial-institute/files/the_attractiveness_of_senior_ judicial_appointment_research_report.pdf $>$.

14 See $n 4$ above.

15 See the two reports by UCL's Judicial Institute at <www.judiciary.uk/wp-content/uploads/2015/02/jac-2014results.pdf> and <www.judiciary.uk/wp-content/uploads/2017/02/jas-2016-england-wales-court-uktribunals-7-february-2017.pdf $>$.

16 See the Senior Salaries Review Board, Thirty Ninth Annual Report on Senior Salaries 2017, Report 87 (CM 9455 , 2017) and its follow-up work in the NatCen, Survey of Newly Appointed Judges in the UK in 2017 (2018) $<$ www.gov.uk/government/publications/natcen-report-on-survey-of-newly-appointed-judges-in-the-uk$2017>$.

17 House of Lords Select Committee on the Constitution, Judicial Appointments: Follow-up (HL Paper 32, 20172019) <https://assets.publishing.service.gov.uk/government/uploads/system/uploads/attachment_data/ file/629679/SSRB_2017_report_Print.pdf $>$. 
In Northern Ireland, the general position on judicial appointments has been fairly well researched. ${ }^{18}$ Although the research discussed in this paper is the first study looking at the specific issue of High Court appointments in Northern Ireland, there is some information that can be read across from the work carried out for the UK as a whole, as well as a number of internal reports that can be read alongside NIJAC's reports. ${ }^{19}$ The existing reports revealed a number of themes which were explored further during the research which is now being presented.

\section{Pay and pensions as barriers}

Amongst the commonest barriers to senior judicial appointments mentioned to us by our interviewees were: (a) the relatively low salary attached to the position of High Court judge in comparison with the higher salaries earned by successful QCs and senior partners in firms of solicitors; and (b) the changes applied to the judicial pension scheme in 2015.

\section{PAY}

In the financial year 2018-2019 the salary of a puisne High Court judge in Northern Ireland (as in England and Wales) was f,185,197. From 1 April 2019 it has been $£ 188,901 .{ }^{20}$ The Senior Salaries Review Board confirmed in 2018 that judicial salaries had been allowed to fall far below the levels they should have been at, and it therefore recommended that the salary of a High Court judge should be raised by 32 per cent to $£ 240,000$, backdated to April 2018. On 26 October 2018 the Lord Chancellor announced that judicial pay for 2018-2019 would rise by just 2 per cent - still the biggest rise in 10 years - and in June 2019 the Ministry of Justice introduced a new temporary allowance for High Court judges in England and Wales in order to improve retention and recruitment. ${ }^{21}$ The new allowance is to be backdated to 1 April 2019 and has been set at 25 per cent of a High Court judge's basic salary, replacing the previous allowance of 11 per cent which was introduced in 2017. It applies only to High Court judges who are already, or will become, eligible for the new judicial pension scheme introduced in 2015, and it will remain in place only until a sustainable long-term solution is introduced to deal with the pension problems (on which see the next section of this article). ${ }^{22}$ The Ministry of Justice is working with the devolved administrations in Northern Ireland and Scotland as regards

18 Queen's University Belfast, Propensity to Apply for Judicial Office under the New Northern Ireland Judicial Appointments System: A Qualitative Study for the Northern Ireland Judicial Appointments Commission (2008) and Rewarding Merit in Judicial Appointments? A Research Project Undertaken by the School of Law, Queen's University Belfast for the Northern Ireland Judicial Appointments Commission (2013) and further commentary and analysis of these reports in J Morison, 'Finding Merit in Judicial Appointments' in C Dwyer and A-M McAlinden (eds), Justice in Transition (Hart 2015) and in J Morison, 'Beyond Merit: The New Challenge for Judicial Appointments' in G Gee and E Rackley (eds), Debating Judicial Appointments in an Age of Diversity (Routledge 2017) 223-239.

19 B Coulter and E Doyle, Review of the Effectiveness of NIJAC's Appointments Process (2018); Lord Chief Justice's Office, Results of Survey of QCs on Barriers to Seeking Judicial Appointment (2018) and NIJAC's Annual Reports and Accounts dating from 2006 <www.nijac.gov.uk/publications/type/annualReport?search_api_ views_fulltext $=$ annual $\% 20$ action $=$ search $>$.

20 See the announcement by the Ministry of Justice at $3<$ https://assets.publishing.service.gov.uk/ government/uploads/system/uploads/attachment_data/file/836749/judicial-salary-schedule-oct2019.pdf $>$.

21 For details, see Government Response to Report No 90 of the SSRB: Major Review of the Judicial Salary Structure (5 June 2019, CP 107) <https://assets.publishing.service.gov.uk/government/uploads/system/uploads/ attachment_data/file/806480/government-response-ssrb-june-2019.PDF $>$. See too Owen Boycott, 'High Court Judges Get Pay Rise to Deal with Hiring Crisis in England and Wales' The Guardian (London, 5 June 2019) <www.theguardian.com/uk-news/2019/jun/05/uk-high-court-judges-to-be-given-25-pay-rise-totackle-hiring-crisis $>$.

22 Ibid paras 19-22. 
the changes that may be made in those jurisdictions, and further details are to be announced in due course. 23

Although the average earnings of QCs in Northern Ireland during that or any other year is not known, it is an accepted fact that many QCs regularly earn much more than the salary of a High Court judge each year. As long ago as 2012 it was disclosed in an answer to a question put to the Minister for Justice in the Northern Ireland Executive by Jim Allister MLA that in the five previous financial years 21 Queen's Counsel had each earned more than $f, 1,000,000$ in legal aid payments alone and $f, 55,000,000$ was awarded to 70 QCs in all. ${ }^{24}$ Although legal aid payments have been reduced since 2012, considerable rewards are still available to barristers and solicitors through non-publicly funded work. As far as solicitors are concerned, the head of the Belfast branch of an international firm asked us rhetorically why he or she would want to take a 50 per cent pay cut in order to become a High Court judge.

It seems clear, certainly, that in Northern Ireland there is a cadre of high-earning lawyers who, at present, are not likely to be interested in applying to become a High Court judge because they would be significantly better off financially if they stayed in their current job. As discussed in section 3 of this paper, they may be individuals who find their current work much more enjoyable than the work they anticipate having to do as a High Court Judge. We know from Turenne and Bell's report that the same situation obtains in England and Wales, ${ }^{25}$ although those authors also noted that for solicitors in Northern Ireland the judicial salary is 'often close enough to what would be received in private practice'. ${ }^{26}$ They said the same about solicitors in Scotland but also cited a survey by the Law Society of Scotland which indicated that, in 2017, at least 25 per cent of all solicitors, regardless of the size of the firm where they were working, earned more than $f^{200,000}$ per year. ${ }^{27}$

It is equally clear that pay, in and of itself, is not a barrier to High Court appointment as far as serving County Court judges in Northern Ireland are concerned. In 2018-2019 the salary of a County Court judge was $£, 148,527^{28}$ (with the Recorder of Belfast receiving an 8 per cent uplift), meaning that, for applicants from that pool, promotion to the High Court would entail a pay rise of almost 25 per cent. Lawyers working in the public sector - for example, in the Public Prosecution Service or the Crown Solicitors Office - would also be earning much less than the salary of a High Court judge, indeed less than that of a County Court judge too.

23 Ibid para 23.

24 Adrian Rutherford, 'Revealed: The QCs and their Legal Aid Millions' Belfast Telegraph (Belfast, 5 June 2012) available at <www.belfasttelegraph.co.uk/news/northern-ireland/revealed-the-qcs-and-their-legal-aidmillions-28756954.html>. See too the Belfast Telegraph of 25 June 2013 <www.belfasttelegraph.co.uk/news/northern-ireland/lawyers-paid-100m-in-legal-aid-29371471.html>, 23 December 2013 <www.belfasttelegraph.co.uk/news/northern-ireland/top-legal-aid-barrister-earned-1m29862020.html> and 24 December 2013 <www.belfasttelegraph.co.uk/news/northern-ireland/northernireland-90m-legal-aid-gravy-train-not-sustainable-says-mla-29863234.html>. Turenne and Bell (n 3) paras 32-38.

26 Ibid para 33.

27 Financial Benchmarking Survey Overview <www.services.tribalgroup.com/apps/LSS_Reports>.

28 This pay is slightly higher than that earned by Circuit judges in England and Wales because of the fact that County Court judges in Northern Ireland may be required to preside in serious criminal cases without the assistance of a jury (in terrorism-related cases). For 2019-2020 the salary of a County Court judge in Northern Ireland was raised to $£ 151,498$ : see n 20 at 4. 


\section{PENSIONS}

The pension arrangements for all judges in Northern Ireland, as in the rest of the UK, were radically altered by the Judicial Pension Regulations 2015. The changes were described to us by one judge as the 'biggest obstacle for the traditional applicants . . . for both silks and partners in large successful commercial practices'. The 2015 Regulations affected judges in three different ways depending on their length of service and their date of birth:

1 those who were members of the judicial pension scheme before 1 April 2012 and were born before 2 April 1957 retained full protection;

2 those who were members of the scheme before 1 April 2012 and were born between 2 April 1957 and 1 September 1960 were entitled to tapering protection until a date between 31 May 2015 and 31 January 2022, whereupon they are to be excluded from the scheme and become entitled to join the new scheme (they also acquired the option to transfer to the new scheme on 1 April 2015);

3 those who were members of the scheme before 1 April 2012 but were born after 1 September 1960 were not entitled to any protection and were excluded from membership of the scheme after 1 April 2015, on which date they were able to join the new scheme.

It follows that judges who fell within the third category were treated less favourably than those who fell within the first and second categories, and those who fell within the second category were treated less favourably than those who fell within the first category. The factor determining which category a judge fell into was their date of birth. In December 2018 the Court of Appeal of England and Wales confirmed the decision of the Employment Appeal Tribunal (and of the employment tribunal below that) that the changes to the pension scheme discriminated against certain judges on the ground of their age and that the Lord Chancellor and Ministry of Justice had failed to show that such discriminatory treatment was a proportionate means of achieving a legitimate aim. ${ }^{29}$ In June 2019 the UK Supreme Court refused leave to appeal this decision, which means that the UK government may be required to compensate those judges who have been unfairly discriminated against on age grounds. As things stand, however, judges who were not members of the judicial pension scheme before 1 April 2012 will apparently not qualify for any such compensation. We were told that complaints about age discrimination in the implementation of the new judicial pension scheme had also been made by various judges in Northern Ireland and that the determination of those complaints had been put on hold until the final outcome of the litigation in England and Wales was known. Whatever remedy is eventually put in place for the victims of the age discrimination there, it is likely that it will be replicated in Northern Ireland too in due course.

It is clear that some High Court judges, particularly the younger ones, now have pension arrangements which are not as generous as those previously in place. But in that respect those judges are no different from many other categories of workers in the public sector whose final-salary pension schemes have recently been abolished or radically altered and whose predecessors in their jobs were treated more favourably. Moreover, we heard from several interviewees that successful barristers, like other self-employed individuals and practising solicitors, usually build up their own private pension pot over a number of years

29 The Lord Chancellor v McCloud [2018] EWCA Civ 2844 (20 December 2018). The details of the schemes are set out in paras 12-24 of the Court of Appeal's judgment. 
through savings and investments. If they become senior judges, they will still enjoy the benefits of that pension pot in addition to the pension which they will receive under the new judicial pension scheme when they retire from the bench. In addition, the pension problem is a transient one because, as time goes, by applicants for senior judicial appointments will no longer feel aggrieved that the previous very generous pension scheme is no longer available to new appointees. Changes to tax rates, moreover, are a vicissitude which all workers throughout the country have to face from time to time, and there appears to be no justification for treating members of the judiciary as a special case. ${ }^{30}$

In short, while recognising that the change in pension arrangements has affected some serving judges quite adversely, it is a phenomenon which affects all tiers of the judiciary, as well as many other public-sector workforces, and it is unlikely to be a discernible barrier to lawyers who are considering whether to apply for future senior judicial posts.

\section{The nature of the job as a barrier}

Research conducted for the NatCen Survey of Newly Appointed Judges suggests that those who join the judiciary are motivated by the idea of undertaking a challenging job, providing a valuable public service and taking what may be seen as a natural career step. Moreover, these expectations are generally fulfilled. ${ }^{31}$ Turenne and Bell list the main incentives for applying for appointment as a reduction of workload and pressure compared to private practice, a secure salary (albeit often smaller), a good pension, respected social status and a wish to put something back into the legal system. Our interviewees in Northern Ireland confirmed these incentives to a degree, but they also pointed to a number of changes to the way (barristers and solicitors) work and to the workload of judges, the combined effect of which has had an adverse impact on the attractiveness of a judicial role.

\section{ChANGes to THE JOB OF LEGAL PRACTITIONERS}

The life of the practitioner has changed in recent decades. We were told, for example, that 20 or so years ago there was both more work available and considerably more pressure to take what was on offer. In this context, despite the reduced salary, a judicial appointment had a particular appeal. As one current judge told us, 'in the past the bench was seen as an escape from the unrelenting pressure of work, one case after another'. Nowadays, the nature of practice is said to have changed. The same judge pointed out that:

... now the vast majority [of barristers] have a much better work/life balance ... [for me] there was no question of taking time off to go skiing ... [but] now you can organise your cases ... there is less work available... [but] you can still have a decent life.

Several of our female interviewees particularly stressed the importance of this flexibility.

Both barristers and solicitors told us that now even very successful practitioners have considerably more control over their work. Indeed, a senior partner in a solicitors' firm referred to the hierarchy and formality of the 'back corridor' (the area in the Royal Courts of Justice building where High Court judges have their chambers) as comparing unfavourably to the collaborative and teamwork approach adopted in the modern

30 Judges in Ireland strongly campaigned against cuts to their pay and pensions after emergency measures were taken to reduce public expenditure in the wake of the financial crisis in that country in 2008. Despite dissatisfaction on the part of many serving judges, the changes do not appear to have had much of an effect on the willingness of lawyers to accept senior judicial appointments since that date.

31 Above n 8. 
solicitors' firm, where diversity and flexibility in working patterns are valued for business reasons. Similarly, as a senior barrister put it:

I am going to have to come in every day of the week. I am going to have a boss ... who will tell me where I have to go and what cases I have to hear . . . and my holidays are going to be cut back ... and all this for a cut in pay.

To be fair, we heard contrasting views as well. One judge with experience of the back corridor thought it was 'very collegiate', and several such judges told us they could easily informally consult one of their colleagues on a legal point if they felt the need to do so. Another judge appreciated the variety and challenges which High Court work presented.

It seems, nevertheless, that some modernisation of the working conditions of judges might be worth consideration. In particular, as one QC put it, 'if there was the option of having part-time hours that would make it much more attractive'. While this is problematic in terms of the statutory provisions setting out the establishment of the judiciary, it is an important suggestion to consider for the future. Two judges told us, however, that it would not make sense to appoint a part-time judge unless he or she could commit to being available for a two- or three-month period at a time and thereby able to take on long cases. Similarly, there was support from at least three serving High Court judges for the idea of targeting recruitment at senior practitioners, perhaps in their sixties, on either a full-time or part-time basis, and perhaps with an extension to their retirement age. ${ }^{32}$ We return to the issue of part-time and flexible working below. ${ }^{33}$

\section{Changes to the job of High Court judges}

At the same time as the work of practitioners has become more flexible, the work level required of High Court judges has intensified. Several interviewees mentioned that the volume of work is much greater now than it was 20 years ago. Most judges accept this. As one said:

... there are a lot of good things about being on the bench and most people broadly enjoy it ... [W] hen I applied I did expect that I would have to work pretty hard ... At times you would feel a little stressed but no more than at the Bar... we shouldn't be too defensive.

Indeed, all of the serving and retired High Court judges we interviewed told us that the experience of serving as a High Court judge was enjoyable, and none expressed any regrets at having taken up the role.

However, legacy cases relating to the troubles in Northern Ireland (e.g. inquests, compensation claims and judicial reviews of actions or inactions by the police) and historic sex abuse cases were seen as particularly difficult and unattractive. One judge spoke eloquently about the difficulties he has had as an older person in going back into the past to revisit former times in order to try to apply modern standards to old cases. We were also told that the current political situation in Northern Ireland, where the Executive and Assembly have not met since March 2017, has put additional pressure on judges who are finding that issues are being passed to the judiciary in the absence of any other decision-making forum. This arises from the fact that the Northern Ireland (Executive Formation and Exercise of Functions) Act 2018 leaves it uncertain as to what decisions

32 See further comments made by Lady Hale to the House of Lords Constitution Committee, reported in The Times, 28 March 2019 <www.thetimes.co.uk/article/let-judges-stay-on-until-72-urges-hale-k8txk3mts>.

33 See pp 497-498 below. 
can or cannot be taken by civil servants in the absence of a serving minister. ${ }^{34}$ While concerns about security are no longer very prevalent, the compensations of the status of the post, including the knighthood or damehood, are perhaps no longer sufficient to overcome the issues about isolation and the effect on family life that still persist.

Concerns were expressed too about the variety of specialisms that might be involved in the High Court, some of which might be far from an applicant's expertise in the increasingly specialist world of legal practice. We were told that, 'by the time you got to the stage in your career where you were ready to apply to a High Court job . . . you will be a specialist and then you then have to go back to being a generalist'. As one QC put it, 'You may find that you're pitched in somewhere . . like the Family Division where you never had any experience or interest and you can do very little about it.' This might be an argument for increased training of new judges or, alternatively, for ensuring that judges are appointed more directly to particular specialisms rather than rotating across areas of law. Such changes might assist in widening those attracted to making an application. One interviewee told us, 'I believe that it would encourage solicitors in particular who have a speciality ... I am a criminal lawyer, what do I know about Chancery cases?' At the same time a serving judge commented that one of the attractions of the post was 'the new challenge ... You are being asked to do things that are difficult . . . and moving into a different area of law.'

The effects of austerity too are being felt, reinforcing views found in the wider literature about judges' working conditions. ${ }^{35}$ While we did not find the same complaints about facilities in the High Court of Northern Ireland as others have reported in Great Britain, there is a sense in which the funding environment has sapped morale. As one judge put it: 'austerity has been a factor . . . ideas which could help judges be more efficient are not viewed favourably at this time ... there is a lot of scope here ... [for] someone to do research and work with and provide a critical perspective'. Indeed, the idea of judicial assistants was popular both with serving judges and with some potential applicants. As one judge observed, confirming the considerable support amongst nearly all of the serving High Court judges we interviewed for an enhanced system of judicial assistants, 'it would really help to have someone . . . setting out the background, explaining, for example, the contractual framework in a complex case . . . or doing a bit of research on the caselaw'. Another linked this to the increase in personal litigants, remarking that: 'I get nothing from them [in terms of legal argument] . . . and end up having to go and do my own research.'

This is an area in which reforms could be introduced to considerable effect. A small research unit already exists in the Royal Courts of Justice, but in practice it is available for use only by judges who are sitting in the Court of Appeal. While there is a system of tipstaffs who attend judges, they are not really involved in legal work. Securing more

34 The Act was passed as a consequence of the decision of the Court of Appeal of Northern Ireland in In re Buick [2018] NICA 26, where the court held that, in the absence of a Minister, the relevant government department did not have the power to make a decision to grant planning permission for a major waste incinerator. Section 3(1) of the Act provides: 'The absence of Northern Ireland Ministers does not prevent a senior officer of a Northern Ireland department from exercising a function of the department during the period for forming an Executive if the officer is satisfied that it is in the public interest to exercise the function during that period.' When the Attorney-General of Northern Ireland referred the issue of the extent of departmental powers to the Supreme Court, the Justices adjourned the reference because it preferred to determine such an issue against the background of a clear factual matrix: Reference by the Attorney General for Northern Ireland of devolution issues to the Supreme Court pursuant to Paragraph 34 of Schedule 10 to the Northern Ireland Act 1998 (No 2) [2019] UKSC 1.

35 See Turenne and Bell (n 3$) 19$. 
funding for proper support staff for judges would be a development that would make the judicial role more attractive to potential applicants. High Court judges appointed in the Republic of Ireland are now assigned a judicial assistant rather than a tipstaff, although there is apparently some dissatisfaction with the system. ${ }^{36}$ Judicial assistants also play a significant role in the judicial apparatus of other jurisdictions; in particular, they are given very high esteem in the Netherlands. ${ }^{37}$

\section{The recruitment process as a barrier}

\section{GENERAL IMPRESSIONS}

Overall the recruitment process is not a major problem. As one QC told us, 'I don't see any barriers as such . . . I just wouldn't be interested in the job.' However, several interviewees did tell us that some things were amiss with the recruitment process. One said that 'the application process is not terribly effective', adding that 'proof of [judicial] experience should count as proof of ability'. Another said that 'the system itself is irredeemably flawed . . . because there is a [recruitment] panel of four, two of whom are lay people'; the same interviewee described this process as 'not efficient'. A judicial interviewee observed that 'the current selection system is incredibly mathematical and moderated marks cause problems too ... Obviously the process of appointment is putting off people.' Despite all these comments, most interviewees were otherwise positive about the role of NIJAC in running the competitions for High Court positions.

\section{DEMONSTRATING ABILITIES, QUALITIES AND SKILLS}

It was frequently suggested to us that barristers were disincentivised by the fact that they had to complete an application form in which they were expected to provide evidence for how they had acquired certain abilities, qualities and skills. Being self-employed, many barristers will rarely if ever have had to complete such a form in the past. This was considered to be in contrast to lawyers working in the public sector, who routinely apply for higher-grade posts and in the process are tested on a range of competencies.

We can see nothing out of place in the list of abilities, qualities and skills which applicants for High Court positions are expected to possess, and it is appropriate that in relation to each of the five abilities, qualities and skills that are listed on the application form applicants are required to provide evidence demonstrating, through the use of examples from their own experience, how they meet the characteristics set out in the three or four bullet points under each of the five headings.

The Applicant Information Booklet informs applicants that the distribution of marks in the assessment is as follows: 40 per cent for intellectual capacity, knowledge and expertise; 15 per cent for personal qualities; 15 per cent for understanding and fairness; 15 per cent for communication skills; and 15 per cent for leadership and management skills. This seems to us to be a reasonable allocation of marks, but we suggest that it might be worthwhile further disaggregating the 40 per cent allocated to intellectual capacity, knowledge and expertise into smaller amounts, such as 10 per cent for intellectual capacity (always very difficult to assess), 15 per cent for knowledge and 15 per cent for relevant expertise. Amongst other benefits, this might allow previous judicial

36 Conor Gallagher, 'Judges Unhappy with Assistants' Support and Want Ushers Back' Irish Times (Dublin, 24 November 2017) <www.irishtimes.com/news/crime-and-law/judges-unhappy-with-assistants-support-andwant-ushers-back-1.3303136>.

37 Nina Holvast, 'Considering the Consequences of Increased Reliance on Judicial Assistants. A Case Study on Dutch Courts' (2014) 21 International Journal of the Legal Profession 1. 
experience to be given some explicit weight in the selection process. We have been told that this is now under review.

\section{THE SUBMISSION OF WRITTEN WORK}

Applicants are also required to submit three pieces of 'written work of substance'. NIJAC's website contains a cover page for whatever is submitted. This page makes it clear that the three pieces should demonstrate the applicant's 'abilities, qualities and skills ... and how these could potentially transfer to [the work] expected of a High Court judge'.

The written work that must be submitted by applicants as evidence of their writing ability was seen as problematic by some of our interviewees, both those who had succeeded in being appointed to a judicial role and those who had not. There was a feeling that NIJAC's Selection Committees were more impressed by examples of senior counsel's opinions than by, say, a judgment issued by a County Court judge or academic material (even in book form) submitted by a lawyer in public service. We were told by one interviewee that a County Court judge who applied for a High Court post did not have any written judgment available to submit and that another such applicant submitted a judgment that was flawed. One County Court judge was emphatic that the nature of their work was not suitable for producing polished judgments which might impress a selection panel. The same judge told us that 'the barrister's opinion is very much part of their dayto-day job in the way that it is not for us' and that, while County Court judges could of course write up a 'vanity judgment' with a view to advancing themselves, the pressure of day-to-day working life was such that they would need to make a special effort to focus on doing so as part of an application process.

Several of our solicitor interviewees felt that may have the evidence of high-quality written work but complained that they may have 'a chip on [their] shoulders . . . [W] don't recognise the evidence that exists . . . [H] ow can you compare a commercial lease ... with maybe a very good use of precedent . . . a "must" instead of a "shall". . . against an opinion setting out the salient points . . . ?'

Interviewees employed as government lawyers told us that it was difficult for them to submit written material which met the stated criteria because the documents they have written are not theirs to share - they are owned by the parties to the cases in question. In any event, many documents they generate are 'joint efforts', and it can be almost impossible for an applicant from that sector to identify specific parts of the documents which were written exclusively by them.

Generally speaking, concerns were expressed by several interviewees over the fairness of this element of the selection process, especially as the Applicant Information Booklet and the cover page, despite being quite wordy on the matter, do not specify precisely what qualities are being looked for in the written submissions. Nor is there any word limit to what can be submitted and, on occasions, the assessment of submissions must be akin to comparing apples and oranges. As one interviewee remarked: 'What is the purpose behind asking for this? Is this something that could be properly, fairly and more consistently approached as part of the actual assessment process? . . . You could [instead] be asked to read something and write up a brief summary judgment.'

We were left with the distinct impression that more could be done to reduce applicants' understandable anxieties relating to this element of the selection process and that more could be tested at this stage. We also discussed with interviewees whether in this context 'merit' might mean more than straightforward intellectual ability and encompass an ability to run a court decisively and efficiently. This might provide an 
opportunity for all applicants to come away from the recruitment process with an equal sense of its fairness. While it may be difficult to produce metrics to demonstrate such additional attributes, the general opinion amongst our interviewees (especially serving and retired County Court judges) was that there are important abilities, qualities and skills that are not presently assessed and, in particular, previous judicial experience is not given sufficient consideration.

\section{CONSULTEES AND REFEREES}

It was noted by several of our interlocutors that NIJAC's abandonment of 'consultees' during recruitment competitions was a good thing. It means that applicants who are close to existing judges cannot capitalise upon that coincidence in order to boost their application. But one High Court judge was of the very definite view that it was a mistake not to make use of consultees, saying 'I know who is High Court material and who is not.' Another High Court judge suggested that all existing High Court judges should be asked for their views on the candidates being considered by NIJAC (as was supposedly the practice in the past), and another said that the removal of this practice represented a diminution of their status. Our own view is that such consultations should not take place: provided that NIJAC's selection process is rigorous in obtaining as much information as possible about the knowledge and competencies of the applicants (together with honest references), a level-playing field is maintained and the risk of discriminatory treatment or unconscious bias around the nature of what constitutes 'merit' is reduced.

Reliance on references, particularly if the referee is asked to comment specifically on key abilities, qualities and skills in which good applicants are expected to excel, helps to preserve an equal opportunities approach to recruitment. But it was pointed out to us by one senior counsel that non-advocate applicants for the High Court may have difficulty in finding a serving judge who knows their work well enough to provide an impressive reference. Of course, there is no requirement to have a serving judge act as a referee, but doubtless a positive reference from such a person would carry considerable weight. The same source said that the fact that so few solicitors are appointed to the bench was ironic because, on the whole, solicitors are better than barristers at managing cases. But we acknowledge that senior solicitors who apply for a position in the High Court are very likely to know other senior people not just in the law but in other walks of life and therefore should have little difficulty in calling upon them to act as referees.

The key point here is that Selection Committees should not attribute undue weight to a reference just because it emanates from a senior judge. We understand that references are not given 'marks' as such, but they are taken into account by the Selection Committees when they are considering all the other evidence they have collected about the candidates' abilities, qualities and skills during the appointments process. The purpose of the reference is to allow the Committees to confirm the accuracy of information which the Selection Committees already possess.

\section{Personal KNOWLEDGe of applicants}

The interviewees we spoke to differed greatly as regards the appropriateness of members of Selection Committees, taking into account their own personal knowledge of applicants when assessing them. One very experienced judge said it was 'ludicrous' not to allow such personal knowledge to be used, although that judge did not go so far as to suggest that the panel member could fill in the blanks of an acquaintance's poorly completed application form. The same judge thought that Selection Committees should consist only of people who have themselves had judicial experience. But nearly every other 
interviewee who was asked about the selection process was of the view that lay people should be involved at all stages, and that the chairperson did not have to be a judge (in Northern Ireland the chairperson has always been a judge).

Barrister interviewees tended to accept that an applicant could be at a distinct advantage if the judges on the Selection Committee happened to be very familiar with his or her work (while acknowledging that this could be a double-edged sword). ${ }^{38}$ One senior counsel felt strongly that the selectors of judges did need to know the people they were appointing but, when pressed, the lawyer in question could not provide a justification for that view. Another QC said the main point that he or she would like to get across in their interview was that the selection system for High Court judges should be more subjective than at present: the current system was described as too much like a box-ticking exercise.

We were surprised that during our interviews with some judges the names of particular barristers were occasionally mentioned as people who either should have already applied for High Court posts or should be thinking of doing so in the near future. It seems that certain barristers are 'identified' as potential future High Court judges in a way which does not apply to applicants from other pools, such as solicitors, lawyers in public service or even existing County Court judges, all of whom are not so often within the gaze of High Court judges in the courts. Specific barristers are often strongly encouraged to apply by senior serving judges, which is a dangerous course of action because it may lead to unreasonable expectations on the part of such barristers who do apply. Just as canvassing for particular jobs is sometimes stated to be a justification for disqualifying the canvasser from consideration for the job, so those who are selecting people for particular jobs should not be suggesting in any way that a person would be a worthy candidate for the post. Pre-judging a potential applicant in this way is potentially discriminatory against other applicants.

In a small jurisdiction such as Northern Ireland it is unrealistic to expect people on Selection Committees not to be personally acquainted with some of the applicants for judicial posts. However, good practice would dictate not only that such acquaintanceships are notified to the whole Committee in advance of any deliberations taking place but also that the member who knows an applicant does not make any comments about that applicant to other members of the Committee which are not based on something stated by the applicant in his or her application form or during the course of his or her participation in any role-playing exercise or interview.

We were told that NIJAC's conflict of interest policy is based on guidance issued by the Northern Ireland Audit Office, ${ }^{39}$ and this seems appropriate. What is equally important, however, is that the guidance is strictly adhered to. It should be remembered that, according to the guidance, '[a] perception of a conflict of interest can be just as significant as an actual conflict of interest. The key issue is whether there is a risk that a fair-minded outside observer, acting reasonably, would conclude that there is a real possibility of bias. ${ }^{30}$

There is one additional element relating to the appointment process that is particularly eye-catching. Reflecting on the changes to the appointment process brought about by the advent of NIJAC, and its part in demystifying the process and the role of judge, one

38 This notion of 'visibility' was also flagged up in the 2013 study from Queen's University Belfast on the concept of 'merit' (n 18).

39 Presumably, this is Conflicts of Interest: A Good Practice Guide (2015) <www.niauditoffice.gov.uk/sites/ niao/files/media-files/conflicts_of_interest_good_practice_guide.pdf $>$.

40 Ibid para 2.4. 
interviewee told us how the 'tap on the shoulder' recruitment scheme perhaps carried with it 'a sense that it was your duty to do it ... to put something back into the profession $\ldots$ and that seems to have gone now . . . it is a job now'.

\section{Traditions and assumptions as barriers}

\section{THE ASSUMED SUPERIOR SUITABILITY OF SENIOR COUNSEL}

As stated in the introduction to this article, the most usual applicants for High Court appointments during the last decade have been barristers, by far the commonest applicants shortlisted for appointment have been barristers, and the overwhelming majority of those actually appointed have been Queen's Counsel of several years' experience at that level.

Several of our interviewees, including current High Court judges, seemed to take it for granted that senior counsel would be the most likely category of person to merit appointment to the High Court. In particular, Senior Crown Counsel were thought to be particularly eligible with one informant saying 'anyone who was Senior Crown Counsel normally felt that they had to go on to the bench . . . some have enjoyed it . . . one or two of them maybe should not [have made the move]'. When pressed, however, interviewees were not able to provide hard evidence as to why Crown Counsel status or success at the Bar, which tends to be measured in terms of years of experience and perceived income levels, should necessarily mean that those individuals would be better equipped than other applicants to serve as High Court judges. More commonly, we received the impression from judicial interviewees that serving judges who themselves had been successful as senior barristers tended to assume that the competencies displayed in that latter role by the subsequent generation of senior barristers inevitably meant that those individuals too would be likely to be able to perform the work of a High Court judge with aplomb.

When we spoke to solicitors, to lawyers in government service and to serving or retired County Court judges, we were frequently told that the myth that senior barristers must be better equipped for a High Court appointment was just that - a myth. One solicitor told us that:

... the skillset for the High Court puts an emphasis on advocacy . . . court room experience... when in truth the ability to analyse, identify the issues, be methodical and logical and to communicate well and to manage . . . all those things solicitors do bloody well . . . but the job is described in the context of being on your feet, in court.

This connected to a wider view among some non-barrister interviewees that, in the eyes of the High Court judges, their role is of less importance than that of barristers: that solicitors are in effect 'second-class lawyers' and that this is reflected in a range of petty restrictions such as solicitors not being able to even announce in court that a case has been settled, to wear any kind of robe in court or to be addressed as 'my learned friend'. This view seems to cohere with that of senior judicial figures in England and Wales, as enunciated by Lord Neuberger when he argued that 'there is still an in-built assumption that it will tend to be a barrister, not a solicitor, who becomes a High Court judge . . . people on the whole do not think of solicitors - and solicitors do not think of themselves - as becoming High Court judges'. ${ }^{41}$

41 Annual Oral Evidence to the House of Lords Select Committee on the Constitution taken on 29 March 2017 (Session 20162017) Q10 (Lord Neuberger of Abbotsbury) <www.parliament.uk/documents/lordscommittees/constitution/Annual-evidence-2016-17/ucCC290317SupremeCourt.pdf>. 
Naturally, such attitudes are somewhat resented. Solicitors and County Court judges were of the view that applicants from their own professions were often as likely to have the same or better skillsets compared with those of senior barristers. They reminded us that such individuals in their professions will have had to take many important decisions in the course of their careers, that solicitors are likely to be better than barristers at interacting with clients and that County Court judges will by definition be more knowledgeable about and practised in the art of 'court craft' or 'judge craft', that is, the skills required to keep cases running efficiently through the court while ensuring that all points needing to be addressed in each case are dealt with in appropriate detail both during the trial and in any resulting judgment.

The report by Turenne and Bell ${ }^{42}$ did not specifically address the traditional preference given to senior counsel in competitions for High Court appointments. Nevertheless, many of the barriers to appointment which are discussed there apply just as much if not more so to non-traditional recruitment pools. The quantity, complexity and unremittingness of High Court work are as unlikely to be attractive to some nontraditional groups, such as senior solicitors, as they are to experienced barristers. The inflexibility of working hours and practices may be even less appealing to solicitors and lawyers in government service, who may have become used to benefiting from more sympathetic approaches to their caring responsibilities, their health needs and their worklife balance. One of our barrister interviewees commented that he or she would be reluctant to apply for the High Court partly because he or she periodically suffers from depression and did not think that reasonable adjustments would be made to take account of this disability.

\section{THE SUITABILITY OF COUNTY COURT JUDGE APPLICANTS}

Major advantages associated with encouraging applications to the High Court from the County Court bench are that a reduction in salary would be unlikely to play any part in the decision to apply for the job, the applicants would already be familiar with the trappings of judicial office (including the security implications, which are much more significant in Northern Ireland than in England and Wales) and well aware of the responsibilities and 'sacrifices' connected to holding such office. Many of them would be accustomed to the practice of writing court judgments and to the risk of adverse publicity arising out of their handling of a case, and, if they have been appointed to the County Court bench since the establishment of NIJAC in 2005, they would have undergone at least one previous application process and not be as daunted by it as some senior counsel who may have subjected themselves to something similar only when applying for silk. In addition, some County Court judges were previously solicitors, not barristers, so their appointment to the High Court would further assist in embedding diversity at that level. As of June 2019, there were 18 salaried County Court judges in Northern Ireland and 16 fee-paid deputy County Court judges. This constitutes a sizeable pool of potential applicants for High Court positions.

Unfortunately, there is a prevalent view among some barristers and a small number of serving High Court judges that, to be blunt about it, County Court judges would not be intellectually up to the task of serving in the High Court. That is certainly not the official line, as is evidenced by the fact that during the last year or so the Lord Chief Justice has exercised his power to invite a number of County Court judges to spend a number of 
weeks within the Royal Courts of Justice acting as deputy High Court judges. ${ }^{43}$ It seems that a prime motivation for this initiative may have been to meet the business needs of the High Court, particularly given that a vacancy in the High Court has existed for some time. However, it has provided a cadre of County Court judges with the experience of undertaking High Court work (even if, while serving in that Court, they were not paid at the same rate as High Court judges).

Given the shortness of their time in the High Court, it has not always been possible, we were told, to expose the deputy High Court judges to 'big' (i.e. complex or highprofile) cases. This suggests that perhaps this practice is not fulfilling its potential to develop an applicant pool among County Court judges. As one High Court judge put it, these deputy High Court judges 'should be given some of the more heavyweight work to demonstrate that they have the wherewithal to do it . . . [1] would be helpful for the system to give them cases . . . where they can demonstrate their ability'. Nevertheless, those who have undertaken the role do seem to have welcomed the opportunity to do so and have seen it as a way of testing whether the role is attractive. Of course, if the current experiment were to be developed more systematically as a recruitment initiative, rather than as a way of managing business, it would be important that the system offered opportunities on an equal basis. Whether this should involve a role for NIJAC is open to debate, but there is a strong case for saying that it should.

Notwithstanding this recent experiment, there appears to be a view that County Court judges would be unlikely to be able to cope with the pressures of High Court work. It was suggested to us by several interviewees (including one High Court judge) that, if County Court judges were to be appointed to the High Court, they may not be adroit enough at handling fleet-footed senior counsel or at disaggregating the separate legal issues entwined in complex litigation. One senior counsel told us that even a County Court judge with 25 years' experience would not be adequately equipped to deal with what goes on in the High Court. On the other hand, one County Court judge described as 'absolute tripe' the suggestion that senior counsel would inevitably be better than County Court judges at dealing with knotty legal issues. An interviewee with many years of experience in more than one tier of the judiciary did not know why a County Court judge would be more likely to be 'bested' in a High Court hearing by a leading Queen's Counsel than a High Court judge would be, while another suggested that the idea of a County Court judge having the 'wool pulled over their eyes' by an experienced silk was 'a nonsense'.

Negative views about the County Court judiciary were expressed despite the fact that several County Court judges have many years' experience of running Crown Court trials (usually with a jury), including trials where the charges have included murder or serious sexual offences. We were reminded that summing up to a jury can be an 'extremely difficult' task. Criminal law now forms a small part of the workload of the High Court, so perhaps substantial experience in that field is not given as much weight in the selection process as experience in civil or family work is given. In addition, County Court judges hear all the extradition applications in Northern Ireland, which can raise quite complex points of law. They also regularly deal with difficult family law cases in the Family Care Centres, and, in that context, they may have to manage many litigants in person. Difficult

43 Section 7(2) of the Judicature (NI) Act 1978 reads: 'A county court judge shall, if requested to do so by the Lord Chief Justice, sit and act as a judge of the High Court.' Compare the power conferred by s 7(3): see $\mathrm{n}$ 51 below. 
points can arise in civil litigation at the County Court level too, as exemplified all too well when the 'gay cake' case was first litigated in that forum. ${ }^{44}$

A County Court judge was firmly of the view that, because of the consistent failure of County Court judges to be appointed to the High Court in the last decade, there was now a chill factor amongst serving County Court judges which enhanced their reluctance to apply to the High Court. That interviewee knew of one 'very good' County Court judge who applied but did not get to the final assessment stage. A senior counsel - who had already tried to be appointed to the County Court but unsuccessfully - argued strongly that several of the existing County Court judges were easily as good lawyers as some senior counsel.

In England and Wales, Lord Chief Justice Burnett has let it be known that '[p]roper appraisals, consistent with judicial independence, are being rolled out across the judiciary within the resources available to us'. ${ }^{45}$ We are not aware that the same is happening in Northern Ireland. If it were, then County Court judges who are led to believe from their appraisal that they are performing their role particularly well might be more incentivised to apply for a High Court position in due course. Lord Burnett also said:

Career progression within the judiciary is an important factor in increasing diversity at the higher levels. The appointments process should recognise that in the ranks of both salaried and fee-paid judges are many individuals who have not been visible in the higher ranks of the professions, often because they have chosen a career path in the judiciary which is more readily compatible with family life, but who have demonstrated judicial ability. ${ }^{46}$

As examples of the kind of steps being taken in England and Wales to encourage applications for judicial posts Lord Burnett referred to specific pre-application seminars, a Pre-Application (Online) Judicial Education Programme, a Judicial Work Shadowing Scheme, a formal judicial-mentoring scheme, and a scheme enabling individuals to apply for a fixed-term appointment as a temporary High Court judge. ${ }^{47}$ Regarding the last of these initiatives, he pointed out that by 2018 a total of 73 deputy High Court judges had been appointed and that nine of these had subsequently been appointed as permanent High Court judges. ${ }^{48}$

\section{THE BAN ON FORMER JUDGES RETURNING TO PRACTICE}

Applicants for High Court appointments are referred to a document on NIJAC's website called 'Terms and Conditions'. This makes it clear, in paragraph 2.1, that 'The Lord Chancellor regards appointment to the Bench as being for life. Any offer of appointment is therefore made on the understanding that the appointee will not return to practice.' This prohibition on future practice affects all categories of applicant equally, but it is perhaps even more off-putting for younger applicants since resigning from their judicial post after a relatively short time on the bench will entail a greater sacrifice in career terms than it would for an older person. Former High Court judges can become chairs of

44 Lee v Ashers Baking Co Ltd [2015] NICty 2, heard by District Judge Brownlie while sitting as a deputy County Court judge; the case later went to the Court of Appeal ([2016] NICA 23 and 55) and then to the UK Supreme Court ([2018] UKSC 49, [2018] 3 WLR 1294).

45 The Treasurer's Lecture (n 10) 23.

46 Ibid 26.

47 Ibid 27-29.

48 Ibid 29. 
inquiries (Judges Hart and Coghlin are recent examples), arbitrators, mediators or inhouse lawyers, but otherwise they could find it difficult to make a living out of their legal knowledge.

This potential barrier to judicial appointment was not mentioned to us by any interviewee, perhaps because it affects persons who are thinking of applying to lower-tier judicial appointments more so than it does prospective applicants to the High Court. However, Turenne and Bell observe that a number of the people who responded to their question on the issue thought that the prohibition on future practice was 'an unnecessary limitation'. ${ }^{49}$ They also note that the House of Lords Select Committee on the Constitution had received representations from both the Bar and solicitors to the effect that the ban on returning to practice was a disincentive to potential applicants for judicial posts.

\section{ParT-time AND 'FleXITIME' High CourT JUdGes}

This context provides a further justification for the appointment by NIJAC of part-time High Court judges. While previous research on judicial appointments in Northern Ireland suggests that recruitment to judicial posts on a part-time basis may not be appropriate in all circumstances, ${ }^{50}$ there was some support amongst our respondents for part-time working arrangements at the High Court level. Facilitating part-time working can, of course, be of particular benefit to people with dependents, such as those with caring responsibilities. There are already 16 fee-paid part-time County Court judges and 23 feepaid part-time District Judges (Magistrates' Courts), all of whom can be called 'deputy' judges. ${ }^{51}$ They are appointed for five-year terms, although these are renewable provided the appointees retire at the age of 70 . We understand that a few other salaried judges, such as Employment Judges who sit in industrial tribunals, have reduced the number of hours they work and so are now part-time.

It is not currently possible for an advertisement for a permanent High Court post in Northern Ireland to guarantee that the person appointed will be able to work on a parttime basis. Legislation stipulates a maximum number of puisne High Court judges (10), not a maximum number of full-time equivalent High Court posts. ${ }^{52}$ Additional revenue would be required from HM Treasury if more than 10 individuals were to serve as permanent full-time or part-time High Court judges.

But as mentioned above, ${ }^{53}$ section 7(2) of the Judicature (NI) Act 1978 allows the Lord Chief Justice to request a County Court judge to sit and act as a judge of the High Court, and in exercise of that power several County Court judges have recently been invited to serve in that capacity for a few weeks or months. In addition, just after the research discussed in this paper was completed, NIJAC has for the first time approved a method for recruiting up to 10 temporary High Court judges under section 7(3) of the Judicature (NI) Act 1978. This permits NIJAC to appoint persons 'to sit and act as a judge of the High Court as a temporary measure in order to facilitate the disposal of business in the High Court or the Crown Court'. Although the outcome of the competition for

49 Above, n 4 para 101.

50 Above, $\mathrm{n} 5$ at 6.

51 The number of judges was provided by NIJAC, accurate as of 18 April 2019. The relevant legislation does not impose any numbers limits. Deputy County Court judges are appointed by NIJAC under the County Courts Act (NI) 1959, s 107 (as amended), while Deputy District Judges (magistrates' courts) are appointed by NIJAC under the Magistrates' Courts Act (NI) 1964, s 10 (as amended).

52 Judicature (NI) Act 1978, s 2(1), as amended by the Maximum Number of Judges (NI) Order 2004 (SI 2004/1985).

53 Above pp 494-495. 
these temporary posts is not yet clear, the development is one which should be welcomed in principle. We understand from informal discussions with two members of the Bar that the level of interest in the appointments appears to have been high. It is anticipated that in the early part of 2020 a number of temporary High Court judges from varied backgrounds in legal practice will be sworn in. They will initially be appointed for three years, but that period will be renewable, as it is for deputy County Court judges and deputy District Judges (magistrates' courts). When future opportunities arise to compete for positions as permanent High Court judges (there are currently two vacancies within the statutory complement of 10 ), the temporary judges, as well as some individuals who were unsuccessful in the competition for the temporary posts, may well apply.

We discussed with several interviewees whether they thought it would be feasible for a practising barrister or solicitor to try out the role of High Court judge while still maintaining their practice. The consensus (but not the unanimous view) was that it would not be feasible, due not only to the likely clash of diary commitments but also to the potential conflict of interests that might arise in a small jurisdiction like Northern Ireland. But one QC did serve as a deputy High Court judge in the 1990s while still maintaining his practice, and some of the 16 persons who have been appointed as deputy County Court judges continue to work as practising barristers or solicitors. If such 'doublejobbing' is possible at that level, it should also be possible at the High Court level. Such positions may be attractive to practitioners who are nearing the end of their career in practice but who wish to experience one new challenge before retirement. The appointments should help to reduce the workload falling on permanent High Court judges, thereby in due course making their job more attractive to future applicants. Deputy High Court judges who are otherwise practising lawyers (and/or academics) ${ }^{54}$ are common in England and Wales, but we gather that it is easier in that larger jurisdiction for practising lawyers to undertake specialised High Court work on a trial basis without this making it very difficult for them to carry on their own private practice.

The UK government's Advisory Panel on Judicial Diversity produced a report in 2010 which stated that it should be assumed that all posts are capable of being delivered through some form of flexible working arrangements, with exceptions needing justifying, ${ }^{55}$ Of course, quite apart from working on a temporary or part-time basis, all employees, including judges, have the right to request flexible working hours, although no right to demand them. ${ }^{56}$ The request can be made only once a year, but the employer may refuse it only if he or she considers that one or more of a number of stipulated grounds applies, such as that the request would lead to additional costs or would detrimentally affect the ability to meet customer demand. Changes that might allow flexible working were found to have a particular appeal to several of our female interviewees. We understand that the Lord Chief Justice of Northern Ireland is willing to consider requests from High Court judges for some degree of flexibility over holiday periods and days off, but we are not aware that any formal flexitime arrangement has been agreed with any of the current High Court judges.

54 On 24 July 2019 it was announced that Professor Andrew Burrows, Professor of the Law of England at the University of Oxford and a deputy High Court judge, was to be appointed to the UK Supreme Court from June 2020.

55 Report of the Advisory Panel on Judicial Diversity (2010), Recommendation 51.

56 See the Employment Rights (NI) Order 1996, Arts 112F-112I, inserted by the Employment (NI) Oder 2002, Art 15, and the Flexible Working Regs (NI) 2015 (SR 105). 


\section{Judging as a career}

One of the clearest messages we received during the course of our research was that it was remarkable that no County Court judge had made it to the High Court in Northern Ireland since the new NIJAC-run selection system was put in place in 2005. It was suggested to us that the chances of the equivalent level of judges (Circuit judges) being appointed to the High Court in England and Wales are roughly the same (at about one in ten), but that of itself is hardly a justification for the phenomenon in Northern Ireland. It is worth noting that, in the Republic of Ireland, new developments suggest that serving judges in the superior courts will not have to apply at all through the Judicial Appointments Commission for promotion to the High Court, Court of Appeal or Supreme Court, following a significant concession by the Irish government to opponents of the Judicial Appointments Commission Bill that is currently passing through the Oireachtas. ${ }^{57}$ Instead, serving judges will automatically be considered for promotion.

To the informed outsider - someone who is not familiar with the prevailing culture within the various branches of the legal professions - the fact that 'junior' judges do not regularly get appointed as 'senior' judges must seem bizarre. Most people would assume that the persons most likely to make good High Court judges would be those who have already demonstrated their judging abilities in a lower court. As one County Court judge told us, 'the Bar should never be seen as the sole pool or even necessarily the best pool for higher judicial office . . . the skills don't necessarily transfer over.'

Considering the relative skillsets of experienced senior counsel and experienced County Court judges (several of whom would have been senior counsel before being appointed to the County Court), as well as the conversations we have had with several interviewees who have experience of judicial work in the County Court, it may well be that something in the selection process for High Court posts in Northern Ireland is working to the disadvantage of applicants from the County Court. We deduce that the judicial experience already gained by such applicants is perhaps not being given enough weight in the process. While it may be understandable that judges on the Selection Committee who may have come to the High Court through the traditional route (i.e. directly from the ranks of Queen's Counsel) might be prone to unconsciously favour applicants who have a similar background to themselves, it is surprising that lay members of the Selection Committee do not set greater store by an applicant's existing judicial experience when considering their suitability for the High Court.

If in future a common route to the High Court were to consist of many years' experience in the practice of law, in whatever capacity, coupled with several years' experience as a judge at a lower tier in the court system, this would undoubtedly be unpopular within the Bar, especially the senior Bar, but it may well lead to better qualified applicants competing for appointments. Senior barristers have the choice - when they have already been earning high sums for some time - to attempt to divert into the lower tier of the judicial profession if they so wish. The choice is not very different from that facing longstanding junior counsel when confronted with the prospect of applying to take silk: presumably they wish to enjoy the esteem which goes with the move, but they are unsure if they will be able to make a success of the new role. Lawyers who opt to join the lower tier of the judiciary should not then have to conclude that their chances of progressing further up the judicial ladder are no better than one in ten.

We were also made aware by several interviewees, especially those from government legal services (e.g. the Public Prosecution Service) and those attending a meeting of

57 Irish Times (Dublin, 9 May 2019). 
'Presiders', 58 that there seems to be little tradition in Northern Ireland of persons employed as judges in tribunals or as District Judges being promoted to a higher tier of the judiciary. ${ }^{59}$ NIJAC informed us that three individuals who served as fee-paid legal members of tribunals and then as salaried chairs of tribunals subsequently applied successfully to become County Court judges, but the Commission confirmed that to date it has never selected a District Judge (magistrates' courts) to be promoted to the level of full-time County Court judge. That being said, the four District Judges who operate in the civil courts have all been appointed deputy County Court judges as well, and one of them recently became the first such District Judge since NIJAC's establishment in 2005 to be promoted to the position of County Court judge.

We accept that, while it is important that judge-applicants have a proper opportunity to reveal to the Selection Committee the skills they have already acquired while serving as judges, the competition for High Court appointments should not be changed so as to be skewed in favour of judge-applicants. Rather, the skills in question need to be ones which lawyers who have not yet served as judges could still demonstrate based on their legal experience to date. We suggest that these skills could be: (a) an ability to manage a number of cases that need to be processed more or less at the same time; (b) an ability to manage particular cases effectively and efficiently, including an ability to interact successfully with legal practitioners involved in the same case; (c) an ability to make decisions; and (d) an ability to explain decisions in a convincing manner both orally at the time and in writing later.

\section{Conclusion}

The research which has been outlined in this paper bears out, and expands upon, the findings of research conducted in England and Wales. While gender was not a particular focus of this study as it had been in earlier work, ${ }^{60}$ it is still worth considering how many of the barriers may apply to women to a greater degree than they do to men.

Chief among the issues identified in other studies was the negative impact which the current provisions for judicial pay and pensions have had on recruitment to the High Court. This obtains in relation to appointments to High Court positions in Northern Ireland too. Changes require to be made to those provisions. But the research also confirms that there are several other barriers to recruitment which are not related to personal financial circumstances. The legal professions in Northern Ireland, as elsewhere, have changed: becoming a judge is no longer necessarily seen as the pinnacle of a successful career (generally at the Bar). Legal practice in both branches of the profession can be very rewarding without inevitably requiring the sort of commitment of time and energy that is expected of a judge as he or she reaches the final stages of their career. Also, the nature of the work on the bench, sometimes involving historical sex abuse or troubles-related legacy issues, as well as an increase in litigants in person, may for some be less appealing than continuing in specialist practice. Modern working conditions within both branches of the legal profession now involve a degree of flexibility that is not always fully reproduced within the 'back corridor culture' of the High Court, with its limited legal research support structures. Furthermore, the absence of the traditional 'tap on the shoulder' means that there is not always the same pressure as in the past to take one's turn to give something back to the system. There is also a fear of failure and, perhaps most

58 That is, the people who preside over different tiers of the judiciary, whether in courts or in tribunals.

59 In civil law countries, of course, such promotion is normal because they prefer to have a 'career judiciary'.

60 See above $\mathrm{n} 4$. 
significantly, a continuing belief that the main pool for successful applicants will continue to be the senior Bar. This undoubtedly creates a 'chill factor' within those from the County Court or government service who might otherwise be less susceptible to many of the factors that the senior Bar find off-putting.

For some these issues are not enough to deter them from a career in the High Court: the challenge of new work, the sense of public duty and a change in the nature of the pressure of workload were cited as appealing by most of the serving High Court judges we interviewed. However, this appears to be true for fewer potential applicants than in the past, and new pools of talent from existing judicial offices and public service are not replacing the shortfall from the traditional quarters.

While the process of appointment is seen by some potential applicants as daunting, it is generally not perceived as an insurmountable obstacle, although perhaps it should become more widely known that multiple applications may be required before success ensues. Several further steps could be taken to make the High Court recruitment process speedier, fairer and more attractive. Perhaps the most important of these is the development of the temporary position of deputy High Court judge. Some of the people serving in that role could in turn constitute a well-qualified pool of potential applicants for permanent High Court positions. Furthermore, and perhaps this is one of the more important findings, if some of those permanent positions could be available on a parttime or flexitime basis the chances of recruiting a more diverse but still very talented group of High Court judges would be enhanced still further.

Perhaps our most significant finding relates to the issue of the absence of a judicial career path that might resolve the problem of insufficient traditional applicants from the senior Bar. Traditional understandings about progression from the senior Bar to the High Court are no longer delivering the volume of suitable applicants, but existing 'junior' judges from lower tiers are not filling the gap as might be expected in any other field where career progression is often the norm. While not every County Court judge will be suitable for the High Court, there seems to be a strong sense among potential applicants, not only from the County Court but also to an extent from the solicitors' profession and lawyers in public service, that their skills are not as highly valued and that applications from these quarters are less likely to be successful. This means that such applicants are less willing to come forward and, while NIJAC can only consider for appointment those who actually apply, there does appear to be a blockage in the system that requires action to clear. In circumstances where financial, structural and cultural changes to the role both of senior lawyers and of High Court judges limit the capacity of NIJAC as the appointing body to engender sufficient applications of quality from traditional pools, it is vital that the net is widened - by whatever means possible, including most notably the actual appointment of one or more good applicants from the County Court - to ensure that the system is open to catching the most meritorious applicants from wherever they may be currently working. 
